DOI https://doi.org/10.30525/978-9934-26-074-2-7

\title{
НОВІТНЯ ПРАВОВА РЕАЛЬНІСТЬ ЕПОХИ ІНФОРМАЦЙННГО СУСПІЛЬСТВА, ТРАНСФОРМАЦІЯ ПІДХОДІВ ДО ЗАКОНОДАВЧОЇ ДІЯЛЬНОСТІ
}

\author{
Сергєєв К. О. \\ здобувач наукового ступеню кандидата юридичних наук \\ кафедри теорії та історї держави і права \\ Інституту політології та права \\ Національного педагогічного університету імені М. П. Драгоманова \\ м. Київ, Украӥна
}

Динамічний розвиток інформаційних технологій у останні пару десятирічь спровокував зміни структури соціальної організації, в тому числі i у правовому значенні. Словником «Dictionary of Law» закон визначається, як обов'язкове до виконання зведення правил, за допомогою якого здійснюється управління кожним суспільством [1]. Сьогодні ми маємо справу з більш швидким, структурно-складнішим, інформованим і освіченим суспільством. Воно здатне вести діалог у реальному часі і глобальному просторі одночасно всією соціальною групою, впроваджувати новітні практики і змінювати ставлення до існуючих правил в лічені дні. Управляти таким суспільством інструментами закону стає все важче, навіть за активного розвитку інструментів е-демократії, які спрощують деякі процедури. Та на юридичнотеоретичному рівні важливо виділити точні глибинні елементи таких соціальних трансформацій, які впливають на ефективність законодавчої діяльності, як об'єктивні фактори існування закону і його дії.

Одним 3 найважливіших наслідків епохи інформаційного суспільства стала гіпершвидка динаміка поділу праці. Міжнародний поділ праці проявляється в єднанні двох процесів: власний поділ (спеціалізація) та об'єднання (кооперація) [2, с. 197]. Кожна нова професія породжує нові соціальні групи, нові типи господарсько-правових відносин та практик, які потребують державного рішення про регулювання або заборону. Особливого впливу на законодавчу діяльність, набуває процес збільшення кількості соціальних груп на однакову кількість населення. Соціальна група - це сукупність людей, виділена за соціально значимими критеріями (стать, вік, раса, національність, професія, місце проживання, дохід, влада, освіта та ін.). Вона є своєрідним посередником між окремою людиною і суспільством [3]. 
Як фактор, динаміка поділу праці породжує дві новітні вимоги теоретичного переосмислення практики законодавчої діяльності: 1 . Розвиток інструментарних можливостей держави щодо вчасного виявлення таких суспільно-значимих трансформацій; 2. Перегляд загальних доктринальних вимог законодавчої техніки у напрямку створення законів, які можуть зберігати актуальність протягом тривалого часу в епоху гіпердинамічних змін.

Другим наслідком сучасності $\epsilon$ висока динаміка появи новітніх об'єктів права, як винаходів, практик і явищ, як, наприклад, криптовалюти. Об'єкт - важливий елемент правовідносин, що переважно складається 3 речей матеріального світу або прав. Законодавчо об'єкти розподіляють на групи за родовими ознаками, які і підлягають регулюванню незалежно від приватно-визначеної форми (моделі). Але сучасна епоха відзначилась високою динамікою появи новітніх об'єктів, які не включені до жодної з існуючих груп, що зумовлює створення нових порядків регулювання суспільної взаємодії щодо правовідносин, спрямованих на їх отримання. До цієї ж категорії відносяться і динаміки виникнення новітніх практик комунікації, яка впливає на категорію змісту правовідносин, створюючи нові правила поведінки суб'єктів, внаслідок яких вони швидше та ефективніше отримують бажаний об'єкт. Обидва фактори - поява нових об'єктів і нових практик - впливають на різні структурні елементи правовідносин, але мають одну причину виникнення - технологічно доступні інструменти обміну знаннями, які збільшують динаміку появи нових знань та досвіду, як у технологічній, так і у гуманітарній складовій. Щоб винайти колесо, прадавня людина мала звідкись отримати знання про обробку каміння/дерева та про вісь. Щоб застосувати в давній громаді технологічні способи обробки земель, хтось мав принести їх 3 інших місць, продемонструвати та інструментами діалогу пояснити принципи дії та практику соціальної взаємодії для досягнення бажаного результату. Надбання науково-технічного прогресу сприяли формуванню нового, надзвичайно динамічного соціально-економічного середовища, в якому культивується принцип змагальності, руйнування шаблонів та прийняття рішень в режимі реального часу [4, с. 94]. Технологічно доступні інструменти обміну знаннями складають важливий елемент динаміки соціальних трансформацій. Сучасність створила умови до гіпердинамічного руху даних явищ.

Об'єднання двох вищеописаних факторів - динаміки поділу праці, появи нових об'єктів та практик - формують повний склад правовідносин (суб'єкт, об'єкт та зміст) у їх гіпердинамічній швидкості трансформацій у часі. Це фактор нової структури соціальної організації, 
на управління яким сучасні законодавчі процеси не розраховані, оскільки створювались в інших історичних умовах соціальної організації. Інститути управління в умовах глобального світу дедалі частіше вимагають законодавчих повноважень у глобальному масштабі, додаючи нових вимірів у прийнятті законодавчих рішень [5, с. 265].

Законодавча діяльність є нічим іншим, як інженерією соціальних систем. Чим вищі стійкість, оптимальність, доцільність зв'язків між елементами системи, тим вища організованість самої системи [6, с. 274]. Сучасна законодавча діяльність повільніша за динаміку суспільних змін, створює закон, який лишає свою актуальність у значно менші часові терміни, ніж за попередніх епох. Відбулось збільшення елементів комунікації між причиною та наслідком, і, відповідно, зміна комунікаційних потоків причино-наслідкових послідовностей, що ускладнило виявлення істинних причин суспільних явищ, що потребують законодавчого регулювання, та ефективність прийняття державних i політичних рішень.

Ці наслідки вказують на актуальність реформування законодавчих процедур у таких напрямках:

- ретельніше дослідження причино-наслідкових послідовностей соціальних явищ, вдосконалення яких складає предмет законопроекту;

- зміни структури правової норми, спрямованої на збереження актуальності протягом тривалішого періоду часу в умовах високої динаміки технологічних змін та соціальних трансформацій;

- розвиток технологічних інструментів моніторингу соціальних систем та перенесення більшої кількості правовідносин у програмний.

Закон існує в суспільстві для управління суспільством, відповідно i значимі соціальні зміни впливають на його ефективність та здатність до створення очікуваного результату. Епоха інформаційного суспільства сформувала гіпердинамічний порядок соціальних трансформацій, які зумовлюють більшої уваги юридичної науки до існування права на сучасному етапі історичного розвитку.

\section{Література:}

1. «Law - The enforceable body of rules that govern any society» a Dictionary of Law (7 ed.), Jonathan Law and Elizabeth A. Martin, Oxford University Press, 2014.

2. Кривенко Н.В. Міжнародний поділ праці: значення, розвиток та вплив / Стратегія розвитку України, №1, 2016. С. 194-202;

3. Танчин I. 3. Соціологія: Навч. посіб. -3-тє вид., перероб. і доп.К.: Знання, 2008. - 351 с. 
4. Козловець М. А., Соціальна структура українського суспільства в контексті постсоціалістичних трансформацій/ Вісник Національного університету «Юридична академія України імені Ярослава Мудрого» № 4 (35) 2017. C. 41-57.

5. Keebet von Benda-Beckmann \& Bertram Turner (2018) Legal pluralism, social theory, and the state, The Journal of Legal Pluralism and Unofficial Law, 50:3, 255-274. DOI: 10.1080/07329113.2018.1532674

6. Суходубова I. В. Системні властивості законодавства та його співвідношення із системою права/ Економічна теорія та право. № 1 (20) 2015. C. 268-278. 